[学 会 報 告]

\title{
産業保健における職業・環境アレルギー疾患の重要性－第45回日本職業・ 環境アレルギー学会2014報告一
}

\author{
岸川 禮子 ${ }^{1 *}$ ，押川 千恵 ${ }^{2}$
}

${ }^{1}$ 国立病院機構 福岡病院 アレルギー科

2 国立病院機構 福岡病院 耳鼻咽喉科

要旨：第45 回日本職業·環境アレルギー学会総会·学術大会は 2014 年福岡市において, 日本医師会の研修会と 共に開催した。今回の学会は, 認定産業医に職業・環境アレルギー疾患をより深く理解していただく事を目的とし て, 産業医学では高濃度の職場環境物質のヒトへの中毒性·毒性および職業・環境アレルギー学では低濃度の化学・生 物物質による感作・アレルギー発症が焦点となる。いずれもヒトの健康への影響の軽減や安全性の確立が重要であ る。職業・環境アレルギー学会は1970年から開催され現在に至っている。群馬県のこんにゃく製造時に排出される マイコによる気管支喘息や広島県の牡蟈養殖業者におけるホヤ喘息などの重症職業喘息を解明・撲滅したことが当 学会の有名な業績である。ささらに職業性の喘息・鼻炎, 皮膚炎などのアレルギー疾患も個別の対応が予防に繋がる. アレルギー素因のある従業員の疾患の発症を予防し,アレルギー疾患を持つ従業員に適応する職場配慮は, 職場環境 の質が向上する．現在, 産業医学分野における印刷業者の胆管癌発症例やアスベスト暴露による発癌性などへの危 険性の関心が高まっている，従業員の健康と安全を守るために，職場環境の指導者の豊富な知識が望まれる.

キーワード：日本職業・環境アレルギー学会 $(\mathrm{OEA})$, 職業·環境アレルギー, 職業喘息, 認定産業医, 産業医学.

（2014年 8 月 18 日受付, 2014年 10 月 29 日受理）

はじめに

職業·環境に起因するアレルギー疾患について, 産業 医学分野の先生方に広く知っていただき,アレルギー 疾患を持つ従業員のために, 職場環境の質を向上させ ることの重要性を感じ, 日本職業・環境アレルギー学 会 (Japanese Society of Occupational and Environmental Allergy: OEA）としては, 初めての試みとして, 職業・環 境アレルギーと産業医学分野とのジョイント学会を開 催した。

産業医学と日本職業・環境アレルギー学会とは同類 の分野であるが,一方は高濃度による毒性・中毒症状, 他方は低濃度による感作・アレルギー発症が主体とな る状況の違いがある.

\section{日本職業・環境アレルギー学会の経緯}

日本職業・環境アレルギー学会は 1970 年群馬大学の 七条小次郎先生が第 1 回職業アレルギー研究会を開催 され, 毎年開催された $[1,2] .1993$ 年より日本職業ア レルギー学会となり, 群馬大学, 中澤次夫先生が第 1 回 大会を開催された。さらに関連する分野が拡大したた め, 2002 年より日本職業・環境アレルギー学会となり, 横浜市立大学, 池澤善郎先生が第 1 回(研究会から通算 32 回) 大会を開催されて現在に至っている。群馬県の こんにゃく製造時のマイコ喘息, 養蚕喘息や広島県の 牡蠣業者のホヤ喘息の実態と病態が解明され, 職場環 境の改善と適切な治療によって, 地域的な職業に起因 する重症喘息患者が今ではほとんど問題とならなく なったことは有名な事実である。これらの研究会·学

*対応著者：岸川 禮子, 国立病院機構福岡病院アレルギー科, † 811-1394 福岡市南区屋形原 4-39-1, Tel: 092-565-5534, Fax: 092-5660702,E-mail: kishi@mfukuoka2.hosp.go.jp 
会で報告された研究成果から職業喘息の実態解明・治 療・予防の確立がもたらされ, 私自身, 医療と職場環境 における進歩を垣間見ることができた。

\section{第45回日本職業・環境アレルギー学会の主旨}

職場や大気環境中の多くの有機·無機微粒子成分が, ヒトの健康に及ぼす影響を研究者や臨床医が報告する ことで基礎と臨床の情報交換の場となる企画をした． また社会的な背景などの関連も重要であり,社会的背 景が複雑に絡み合ったアレルギー疾患を理解して, 患 者の quality of life (QOL)を高める知識が得られる場と なる努力をした，ヒトの健康を維持するうえで職業・ 環境関連疾患を治療することから予防・予知・啓発活動 が必須の時代となってきたことを認識する必要がある と考えている. 参加される認定産業医の先生方への研 修を兼ねて開催した。2日間で日本医師会産業認定医 生涯研修専門が 10 単位, 日本医師会生涯生涯教育 10 単 位, 日本アレルギー学会参加 4 単位・発表3 単位とかな り高得点を取得できる学会となった。

\section{プログラム}

第45 回日本職業・環境アレルギー学会は一般演題, シンポジウム, セミナー, 講演から構成されている.

Table 1に,6月28日 (土) と29日（日）のプログラムを 示している $[3]$ 。 一般演題では職場環境に関連して発 症した臨床症例のほか, 疫学調査や職場環境の化学物 質の管理では産業医の必要性はないと言われる従業員 50 名以下の小規模企業に管理のニーズが高いなど, 重 要な講演が盛りだくさんであった. Table 1に示す日常 生活の中で起こった臨床例のほか, 講演・シンポジウム では, 職業的に接する化学物質の毒性, 管理のほか, 大 気環境, 環境ホルモンなどが, ヒトに及ぼす健康障害に ついて特集した。一方, 喘息や鼻炎・花粉症, アトピー 性皮膚炎などのアレルギー疾患を持つ人々が, 3 割以上 いると言われている現在, 治療中の患者が, あらゆる職 場で適応できているかなどの問題点に, 焦点を当てた 講演や, 刺されると死に至るアナフィラキシーを起こ す蜂刺しの営林署業務の現状と問題点・対策などを, 詳 細に報告していただいた。学会では, 職業アレルギー 疾患診療ガイドラインを作成している [4]. 今回はそ の内容や今後の展望なども含めて, すぐに役に立つあ らゆる職業性アレルギー疾患の情報提供を行った。

会員は284名だが, 本学会はアレルギー・上下気道呼 吸器・皮膚科分野でさらに職業・環境が重要な位置を占
める拡大した分野になっている.

今回学会の出席者は, 約 300 名で, 研修を兼ねており, 講師による白熱した講演を,熱心に聴講されていた。

\section{おわりに}

学会終了後, すぐに医療情報誌 Medical Tribuneに取 材記事が揭載されており, 胆管癌症例, アスベスト労 災, 喘息の疫学調査におけるたばこの影響が取り上げ られ，これらは普遍的に関心のある話題であったと感 じている.

\section{謝辞}

産業医科大学の森 晃爾先生, 嵐谷 奎一先生, 福岡県 医師会の松田 俊良先生, 大郷 勝三, 他先生ならび日本 職業・環境アレルギー学会会長中澤 次男先生, 事務局 土橋 邦生先生㧍よび多くの理事·監事·役員の先生方 にはご指導, ご支援をいただき, 大変お世話になりまし た。深謝申し上げます。また, 各県医師会産業認定医 の係りの職員㧍よび当院の岩永 知秋院長, 下田照文臨 床研究部長をはじめとして最後まで自分の事のように 頑張っていただいた学会スタッフの方々に, 心よりお 礼申し上げますと共に感謝致します。

なお，第 45 回日本職業・環境アレルギー学会開催に おいては, 多くの企業からの協賛および寄付を賜り, 厚 く㧍礼申し上げます。

\section{利 益 相 反}

この論文においては開示すべきC.O.I.はありません.

\section{引用 文 献}

1. 中村 晋, 荒記俊一(2013)：職業アレルギーー現状 と課題 -。産業医学レビュー26:177-199

2. 土橋邦生, 中澤次夫 (2014)：日本職業・環境アレル ギー学会, 群馬県前橋市. http://oea.umin.jp/(2014.8.1)

3. 岸川禮子 (2014)：第45 回日本職業・環境アレル ギー学会総会・学術大会プログラム・抄録集. 日 本職業・環境アレルギー学会雑誌 22(1): 23-73

4. 日本職業・環境アレルギー学会ガイドライン専門部 会職業性アレルギー疾患診療ガイドライン 2013 作 成委員会 (2013) : 職業性アレルギー疾患診療ガイド ライン 2013. (協和企画, 編), 協和企画, 東京 $167 \mathrm{pp}$ 
Table 1. 第45回日本職業・環境アレルギー学会プログラム

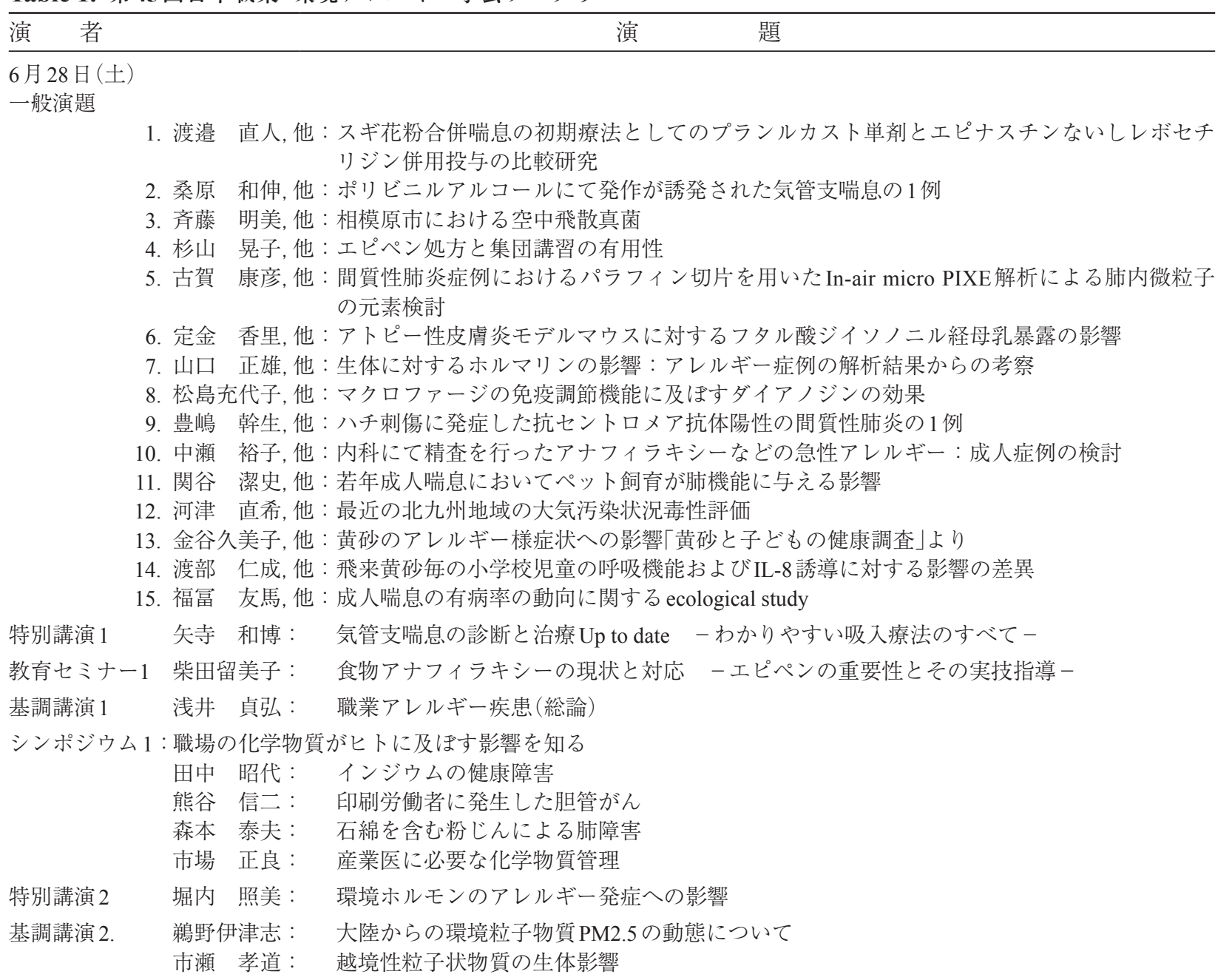

6月29日(日)

会長講演岸川 禮子, 他 : 日本の空中花粉飛散の変遷

一般演題

1. 押川 千恵, 他 : 福岡市の 20 年間のスギ・ヒノキ科花粉捕集数と花粉症患者の変遷

2. 渡邊 直人,他：スギ花粉症に扩けるビャクシンのRAST陽性率の検討

3. 古川瞳,他：ビニルハウス内での長期研究業務に従事したトマト花粉症の 1 例

4. 押方智也子, 他：東日本大震災後に仮設住宅に住居することによって発症したアレルギー性気管支肺アスペ ルギルス症の 1 症例

5. 佐藤 一博： 職業性アレルギー疾患の予防全般㧍よび化学物質の問題

基調講演 3. 森 晃爾：最近の産業保健の課題と労働安全衛生法令の改正 - 化学物質管理を中心に-

特別講演 3. 宇佐神 篤： 職業性アレルギー疾患診療ガイドライン 2013

教育セミナー 2 後藤 穣： スギ花粉症における舌下免疫療法

特別講演 4. 土橋 邦生： 職業性アレルギー疾患の克服に向けた今後の展望

シンポジウム 2 :アレルギー疾患と職業ーアレルギー疾患を持つ従業員と職場環境一

灰田美知子： 気管支喘息の管理に影響する職場の問題

荻野敏：花粉症患者に扔ける労働生産性の損失

杉浦真理子： アトピー性皮膚炎と職場環境について

平田 博国： 職業に関連して蜂刺されの現状と対策 
The Need for Occupational and Environmental Allergology in Occupational Health - The 45th Japanese Society of Occupational and Environmental Allergy Annual Meeting 2014 in Fukuoka -

Reiko KISHIKAWA $^{1}$ and Chie OshiKaWA ${ }^{2}$

${ }^{1}$ Department of Allergology, National Hospital Organization Fukuoka Hospital, Minami ku, Fukuoka City 811-1394, Japan

${ }^{2}$ Department of Otolaryngology, National Hospital Organization Fukuoka Hospital, Minami ku, Fukuoka City 811-1394, Japan

\begin{abstract}
The 45th Japanese Society of Occupational and Environmental Allergy (OEA) Annual Meeting 2014 was held in Fukuoka city in conjunction with a technical course for occupational health physicians to learn occupational and environmental diseases more deeply. Allergic reaction due to low concentrations of chemical and biological materials is important in toxicological diseases due to highly concentrated chemical materials in the field of occupational and environmental medicine. In this paper we describe the activities of the OEA, which was established in 1970 and has completely cured patients with severe occupational asthma, such as the regional Konjac asthma in Gunma prefecture and Sea Squirt asthma in Hiroshima prefecture. Regard for the occupational environment will prevent the onset and/or exacerbation of allergic occupational disease in individual employees with allergy. Occupational cancer of the bile duct and asbestosis are also current, serious issues that should be resolved as soon as possible. It is desirable for the occupational health physician to have a large stock of knowledge about toxicological and allergic diseases in various occupational settings to maintain the health and safety of workers.
\end{abstract}

Key words: OEA, occupational and environmental allergy, occupational asthma, occupational health physician, occupational and environmental medicine.

J UOEH $36(4): 285-288(2014)$ 